\title{
An Investigation on Existence of Momentum in the Stock Exchange of Thailand
}

\author{
Mussa Hussaini', Mohammad Asef Shafaee², Aweng Peter Majok Garang ${ }^{3}$ \\ ${ }^{1}$ School of Management, Asian Institute of Technology, Pathumthani, Thailand \\ ${ }^{2}$ Faculty of Accounting and Management, Qom University, Qom, Iran \\ ${ }^{3}$ Faculty of Economics and Administrative Sciences (FEAS), Erciyes University, Kayseri, Turkey \\ Email:hussainimussa@gmail.com; abhamish78@gmail.com, aweng888_2007@vahoo.com
}

Received 26 February 2016; accepted 22 March 2016; published 25 March 2016

Copyright (C) 2016 by authors and Scientific Research Publishing Inc.

This work is licensed under the Creative Commons Attribution International License (CC BY).

http://creativecommons.org/licenses/by/4.0/

(c) () D Den Access

\begin{abstract}
In the Stock Exchange of Thailand, we examine whether buying stocks that have performed well in the past and selling those stocks that have performed poorly in the past will generate statistically significant positive return in the future. The performance of this strategy has been well studied in different countries by scholars. These studies suggest that past winners tend to outperform past losers in the future. However, academic research in this direction has been limited in countries such as Thailand, and to the best of our knowledge, there has been no such study in Thailand after the financial crisis of 1997. In order to examine the profitability of momentum strategy in Thailand market, six portfolios are constructed according to size and past performances of stocks. Returns on portfolios are calculated on monthly basis over the period from 2010 to 2014. We find that momentum strategy realizes significantly positive return in large size stocks category but not in small size stocks during this period. Furthermore, the equal weighted average of momentum profit of both small and large size categories do not provide any indication of overall momentum profit.
\end{abstract}

\section{Keywords}

Momentum Strategy, Past Loser, Past Winner, Stock Exchange of Thailand

\section{Introduction}

One of the major classifications in stocks market is called momentum strategy. Based on this strategy stocks are classified according to their past performances into past winners and past losers. Momentum in stock market refers to the idea that stocks will keep moving in the same direction. In other word, those stocks with rising in 
price will continue to rise and those stocks with falling in price will continue to fall [1]. According to Asness et al. [2] recent relative winners outperform recent relative losers, they further state that momentum investors believe that increase in price of a stock will be followed by additional increase, and decrease in price will be followed by additional decrease. It is a simple idea and has spread among investors, and many scholars find that this strategy works both in small-cap and large-cap, see e.g. [1]-[4]. However, academic research in this direction has been limited in countries such as Thailand, and to the best of our knowledge, there has been no such study in Thailand after the financial crisis of 1997.

The purpose of this study is to take a closer look at the performance of stocks based on the aforementioned classification in the Stock Exchange of Thailand after the 1997 crisis. The significance of this study stems from the fact that Thailand is an open market and has been encouraging foreign investments as one of the means to enhance employment and promote economic development, technology transfer and the main equity market in Thailand. The Stock Exchange of Thailand is a crucial channel for foreign investment inflow into the country. Chui and Wei [5] contended that the equity market size in Thailand increased from $\$ 1.72$ billion in 1984 to $\$ 133.66$ billion in 1993, an increase of over 77 times within a decade. The main contribution of this paper is for size category in the context of the equity market in Thailand. Almost all previous studies have focused solely on large stocks or indices. This paper extends the scope beyond large stocks and indices by including small and tiny stocks as well. Further, since there is a distinct absence of detailed academic research on momentum strategy in the Stock Exchange of Thailand after the crisis, this paper also contributes to the extension of existing literature of the study. This research is also of significance for those researchers who would like to compare the performance of this strategy in different countries and markets. The rest of the paper is structured as follow: in Section 2 of the paper, an exploration is made into the most recent academic literature in different markets; Section 3 contains the data analysis; research design and methodology which are used to carry out the study are presented in the fourth Section of the paper; while the fifth Section presents the findings of the study and conclusions are made in the sixth Section.

\section{Literature Review}

\subsection{Momentum in US Market}

The strategies in which investors buy those stocks that have generated high returns compare to other stock in the market in recent past and sell those stocks that have generated lower returns compare to other stocks in the market in recent past, gain significant positive return over the next 3 to 12 months [1]. Jegadeesh and Titman [1] analyze the momentum strategy over 3 to 12 months horizon in NYSE and AMEX over the period of 1965 to 1989 and they conclude that buy past winner and sell past loser generate significant abnormal return. Further, they contend that choosing those stocks that have generated higher return relative to other stocks based on past 6 months cumulative return and hold them for the next 6 month, generates $12.01 \%$ on average per year.

Some scholars extend the context of the study and investigate the momentum strategy in different class of stock, i.e. based on market capitalization or based on $\mathrm{B} / \mathrm{M}$ ratio. In this direction Daniel and Titman [6] contend that momentum strategy is higher when they apply for growth stocks compare to value stocks in US market. The result of their study reports that the profit on momentum strategy is close to zero when they applied for value stocks in US.

Hong et al. [7] investigate momentum in US market in NYSE, AMEX, and NASDAQ in respect to market capitalization over the period of 1980 to 1996 . They examine the momentum strategy across different firm size by sorting firms from 1 to 10,1 for smallest and 10 for largest, they find that in those stocks with very small market capitalization ( $\$ 7$ million), momentum strategy realized negative return and by moving to the second size class that is those stocks with $\$ 45$ million market capitalization on average, momentum strategy generates significantly positive return, and for stocks with very high market capitalization the momentum profit tend to decrease nearly to zero.

\subsection{Momentum in International Market}

There are countless studies that have been done on momentum strategy in international market the same as in US market; Rouwenhorst [8] investigates the existence of momentum profit in European countries over the period of 1985 to 1995. Rouwenhorst [8] finds that those portfolios that are composed of past winners generate on 
average 1 percent per month higher return than those portfolios that are composed of past losers. He further concludes that the momentum profit exists in all those countries under the study and it is positive for small stocks as well as large stocks, however, it is larger in those stocks in small size category. More focus on Asian countries, Chui et al. [9] examine the existence on momentum profit in Asian countries over the period of 1986 to 2000. They find that the momentum profit disappears after crisis of 1997 and only half of the countries in the sample generate positive momentum profit after crisis. More specific, they contend that in Thailand the momentum return is positive before crisis but it is weak and not significant after crisis. Some scholars extend the context of the study by investigating more countries, Griffin et al. [4] examine momentum strategy in an international setting consist of 40 countries from 1975 to 1995 . They find that momentum profits are not just the result of short positions in stock with low past return, but also taking long positions in stock with high past return generate higher average return than market indices in long-run. They argue that momentum strategy earn large profit in variety of markets.

Chui et al. [10] also examine momentum in an international context but from different perspective. They argue that within those countries and cultures that value individualism, momentum strategy tend to be stronger and this explains the reason for absence of momentum profit in Japan which ranked low in individualism. Further, they find that there is no momentum profit in four countries namely; Turkey, Japan, Korea, and Taiwan.

Fama and French [3] also study momentum in international stock returns in four regions and they find that momentum strategy works fine everywhere except for Japan, and spreads in average momentum return decreases from smaller to bigger stocks. In other word WML (winner minus loser) return except for Japan are larger for small stocks. They further state that average WML monthly return for small stocks is $0.82 \%$ and for large stocks is $0.41 \%$.

Asness et al. [2] study the value and momentum in international context (US, UK, Europe, and Japan) for different period, 1974 to 2008 for US, 1984 to 2008 for UK, 1988 to 2008 for Continental Europe, and 1985 to 2008 for Japan. They conclude that combined value and momentum generate positive expected return in variety of markets and different asset classes but the momentum in Japan is much weaker than it is in other countries. They further state that the combination of both value and momentum perform even better that either alone which is not consistent with Daniel and Titman [6] findings who argue that momentum profit is higher for growth stocks.

\section{Data Analysis}

In order to study momentum strategy, a 5-year sample period from January 2009 to February 2014 is covered. However, the first momentum sort absorbs a year of data, so the sample period for momentum strategy is effectively from 2010 to 2014. All data are extracted from Stock Exchange of Thailand database (SET Smart), accessed from and available with the Business Research Center at the Thammasat University. SET Smart database contains historical trading prices and indices, listed companies, key statistics information, and information and news.

Yen et al. [11] argue that some part of the premium maybe due to size effect. In order to eliminate this effect they use two-dimension sort in constructing of portfolios which is also used by Basu [12] and Fama and French [3]. In this paper we also use the same method for portfolio formation. Stocks are sorted size and momentum. Portfolios are constructed at end of each month and then evaluated for the next 12 month on monthly basis. In construction of portfolios on size-momentum, stocks also need to be ranked on the basis of their past 12 month's performance in order to separate past winner and past loser. For a stock to be included in these portfolios, it should have at least 2 years of trading data. If any stock does not satisfy these conditions, it is eliminated from the sample. Furthermore, some scholars argue that financial companies have different financial structure so they remove the financial companies from their sample to prevent bias in the final result of value premium [11]. However, Barber and Lyon [13] compare two samples, one with financial companies and one without financial companies and they find that the general final result is not affected by adding financial companies into the sample. In this study financial companies are not excluded from the sample.

\section{Methodology}

At the end of each month, stocks are sorted based on their market capitalization in descending order. Stocks in 
the top $10 \%$ are considered as large stocks and stocks in bottom the $10 \%$ are considered as small stocks. After separating stocks as large stocks and small stocks, in each size category, stocks are ranked based on their past 11 months' cumulative performance in descending order. In the study of momentum strategy, skipping the month of sorting is standard [3]. In other word for portfolios formed at the end of month $t$, the lagged momentum return is a stock's cumulative return for t-11 to t- 1 . Then the top 30\% in each class are considered as past winners and the bottom $30 \%$ are considered as past losers. The middle $40 \%$ are considered as neutral. This method also leads to formation of 6 portfolios; SW, SN, SL, BW, BN, and BL. In this case $\mathrm{S}$ and B indicate small and large caps, while, $\mathrm{N}$, and L indicate winner, neutral, and loser, (top $30 \%$, middle $40 \%$, and bottom $30 \%$ ), respectively and is similar to the method used by Fama and French [3]. After forming portfolios at the end of each month, portfolios are then evaluated on monthly basis using continuously compounded method and Sharpe ratio for the next 12 months starting from the month following the formation of the portfolio. After calculation of monthly returns on each of these portfolios, WML (Winner minus loser) is calculated for each size class, and the overall WML is the equal weight of $\mathrm{WML}_{\mathrm{S}}$ and $\mathrm{WML}_{\mathrm{B}}$. Formulas can be written as follow:

$$
\begin{gathered}
\mathrm{WML}_{\mathrm{S}}=\mathrm{SW}-\mathrm{SL} \\
\mathrm{WML}_{\mathrm{B}}=\mathrm{BW}-\mathrm{BL} \\
\mathrm{WML}=\text { Equal weight of } \mathrm{WML}_{\mathrm{S}} \text { and } \mathrm{WML}_{\mathrm{B}}
\end{gathered}
$$

where, S and B denote small and large, respectively; W stands for winners and L stands for losers.

According to Fama and French [14] stocks in a portfolio can be weighted in two ways; equal-weighted and value-weighted. Chui et al. [9] use the value-weighted method in their study of Asian market with the rationale that small stocks are less liquid in Asian market. Ding et al. [15] also use the value-weighted method and argue that it is logical that stocks with big market capitalization should have a bigger share in a portfolios' return. In this study, following Fama and French [3] we use the value-weighted method and accordingly stocks are weighted in each portfolio based on their market capitalization.

\subsection{Risk-Adjusted Returns}

According to Yen et al. [11] stocks and portfolios should be evaluated both in terms of total return and risk adjusted return. In this study we use the Sharpe ratio for measuring the portfolios performances per unit of risk. Sharpe ratio is calculated for each portfolio formed based on size-momentum namely; SW, SL, BW, and BL. The Sharpe ratio formula can be written as follow:

$$
\text { Sharpe ratio }=\frac{\bar{R}_{p}-\bar{r}_{f}}{\sigma_{p}}
$$

where, $\bar{R}_{p}$ is the average return of the portfolio for a certain period of time which is monthly return in this study; $\bar{r}_{f}$ is risk free rate within the same period of time; and $\sigma_{p}$ is the standard deviation of the portfolio.

The chances that governments default on an obligation denominated in its own currency are almost zero so Treasury bill and government bond are totally risk free rate [16]. In this study, Thailand government Bond 10 years is used as risk free rate.

\section{Findings and Discussion}

Table 1 summarizes the performance of the 4 portfolios formed on the basis of size-momentum namely; SW, SL, BW, and BL over the period of 2010 to 2013. The result in panel A indicate that, over the period between 2010 and 2013 there is a statistically negative difference between average monthly return of small-winners stock portfolios and small-losers stock portfolios $\left(\mathrm{WML}_{\mathrm{S}}\right)$. Based on this result we can conclude that there is a negative momentum profit in small size category. Although, small-winners stock portfolios provide higher average monthly return in comparison to small-losers stock portfolios in 14 of the 39 months of portfolios formation, none of these are statistically significant. Overall, the result demonstrates that small-loser stock portfolios generate higher average monthly return than the small-winner stock portfolios. The average monthly of momentum profit in small stocks category is -1.37 percent with the t-value of -1.897 . In term of risk-adjusted return as well, small-winners portfolios do not outperform small-losers portfolios. Small-winners portfolios have higher average 
Table 1. Summary statistics for portfolios on size-momentum; December 2009-February 2014, 39 months. (a) Small stocks portfolios; (b) Big stocks portfolios; (c) Winners versus losers. The behaviors of past winners' portfolios and past losers' portfolios are studied in Thailand. At the end of each month starting from December 2009, stocks are sorted based on their market capitalization in descending order. Those stocks in the top $10 \%$ are considered as large stocks and those in bottom $10 \%$ considered as small stocks. In each size class, stocks are then ranked in descending order at the end of month t based on their past t-11 to t-1 performance. Top $30 \%$ in each class are considered as past winners and selected to construct size adjusted past winners' portfolios and bottom $30 \%$ are considered as past losers and selected to form size adjusted past losers' portfolios. The middle $40 \%$ are considered as neutral. This leads to formation of 6 portfolios namely; SW, SN, SL, BW, BN, and BL, where S and B stand for small and large and W, N, L stand for winner, neutral, and loser (top 30\%, middle 40\%, and bottom 30\%), respectively. All portfolios are value-weighted. After formation, portfolios are evaluated based on value weighted monthly return for the next 12 months. Winner minus losers (WML) in small size category is $\mathrm{WML}_{\mathrm{S}}=\mathrm{SW}-\mathrm{SL}$ and in large size category is $\mathrm{WML}_{\mathrm{B}}=\mathrm{BW}-\mathrm{BL}$, and the overall WML is the equal weight average of $\mathrm{WML}_{\mathrm{S}}$ and $\mathrm{WML}_{\mathrm{B}}$. Portfolios average monthly returns, standard deviation of the portfolios which is the standard deviation of the portfolios returns, and Sharpe ratio that is used for calculation of the risk adjusted return of the portfolios are reported. The risk free that is used in this study is the 10-year government bond. The t-statistics are given in parenthesis and ${ }^{*}$ indicates that it is significant at $10 \% ;{ }^{* *}$ indicates it is significant at $5 \%$; and ${ }^{* * *}$ indicates it is significant at $1 \%$.

(a)

\begin{tabular}{|c|c|c|c|c|c|c|c|c|c|c|c|}
\hline \multicolumn{12}{|c|}{ Panel A: Small winners portfolios versus small losers portfolios } \\
\hline $\mathrm{T}$ & SW $(\%)$ & $\begin{array}{c}\text { SW S.D } \\
(\%)\end{array}$ & $\begin{array}{l}\text { SW Sharpe } \\
\text { ratio }(\times 100)\end{array}$ & SL $(\%)$ & $\begin{array}{c}\text { SL S.D } \\
(\%)\end{array}$ & $\begin{array}{l}\text { SL Sharpe } \\
\text { ratio }(\times 100)\end{array}$ & $\begin{array}{l}\text { Difference in } \\
\text { S.D (\%) }\end{array}$ & $\mathrm{WML}_{\mathrm{s}}$ & $(\%)$ & $\begin{array}{r}\text { Differenc } \\
\text { SW }\end{array}$ & $\begin{array}{l}\text { Sharpe ratio of } \\
L(\times 100)\end{array}$ \\
\hline 1 & 3.90 & 8.60 & 0.42 & 2.26 & 7.82 & 0.25 & 0.78 & 1.64 & $(0.41)$ & 0.17 & $(0.342)$ \\
\hline 2 & 1.79 & 7.49 & 0.20 & 1.59 & 9.20 & 0.14 & -1.71 & 0.21 & $(0.057)$ & 0.06 & $(0.142)$ \\
\hline 3 & 4.03 & 12.59 & 0.30 & 4.53 & 10.22 & 0.41 & 2.38 & -0.50 & $(-0.116)$ & -0.12 & $(-0.3028)$ \\
\hline 4 & 7.28 & 12.49 & 0.56 & 5.10 & 9.56 & 0.50 & 2.93 & 2.18 & $(0.435)$ & 0.06 & $(0.1248)$ \\
\hline 5 & 5.62 & 10.11 & 0.53 & 5.37 & 10.24 & 0.50 & -0.12 & 0.25 & $(0.059)$ & 0.03 & $(0.0744)$ \\
\hline 6 & 3.61 & 7.62 & 0.43 & 6.23 & 9.25 & 0.64 & -1.63 & -2.62 & $(-0.719)$ & -0.21 & $(-0.4875)$ \\
\hline 7 & 2.19 & 6.77 & 0.28 & 7.72 & 11.40 & 0.65 & -4.63 & -5.54 & $(-1.53)^{*}$ & -0.37 & $(-0.9872)$ \\
\hline 8 & 2.49 & 7.06 & 0.31 & 7.17 & 13.10 & 0.52 & -6.05 & -4.68 & $(-1.183)$ & -0.21 & $(-0.5631)$ \\
\hline 9 & 0.19 & 5.96 & -0.02 & 3.12 & 15.83 & 0.18 & -9.87 & -2.92 & $(-0.684)$ & -0.20 & $(-0.5115)$ \\
\hline 10 & 1.21 & 6.23 & 0.14 & 3.14 & 16.80 & 0.17 & -10.57 & -1.93 & $(-0.396)$ & -0.02 & $(-0.0599)$ \\
\hline 11 & 0.54 & 6.64 & 0.03 & 0.96 & 9.36 & 0.07 & -2.72 & -0.42 & $(-0.129)$ & -0.03 & $(-0.0871)$ \\
\hline 12 & 1.09 & 7.61 & 0.10 & 2.10 & 9.28 & 0.19 & -1.67 & -1.02 & $(-0.294)$ & -0.09 & $(-0.2234)$ \\
\hline 14 & 1.49 & 6.01 & 0.20 & 2.70 & 12.94 & 0.19 & -6.92 & -1.22 & $(-0.318)$ & 0.01 & $(0.0288)$ \\
\hline 15 & 0.89 & 7.34 & 0.08 & 1.89 & 12.20 & 0.13 & -4.86 & -1.00 & $(-0.265)$ & -0.05 & $(-0.1299)$ \\
\hline 16 & 0.75 & 7.20 & 0.06 & -0.12 & 13.23 & -0.03 & -6.04 & 0.87 & $(0.229)$ & 0.09 & $(0.2527)$ \\
\hline 17 & 0.29 & 7.05 & 0.00 & -1.40 & 9.19 & -0.19 & -2.14 & 1.70 & $(0.483)$ & 0.18 & $(0.4367)$ \\
\hline 18 & 0.81 & 8.67 & 0.06 & -0.94 & 8.66 & -0.14 & 0.01 & 1.75 & $(0.467)$ & 0.20 & $(0.4666)$ \\
\hline 19 & 1.20 & 8.83 & 0.10 & -0.91 & 9.46 & -0.13 & -0.63 & 2.11 & $(0.558)$ & 0.23 & $(0.5582)$ \\
\hline 20 & 1.73 & 7.89 & 0.18 & -0.76 & 10.20 & -0.10 & -2.31 & 2.49 & $(0.634)$ & 0.29 & $(0.6601)$ \\
\hline 21 & 2.52 & 7.94 & 0.28 & -0.16 & 8.57 & -0.05 & -0.63 & 2.68 & $(0.743)$ & 0.33 & $(0.7619)$ \\
\hline 22 & 3.15 & 3.70 & 0.77 & 2.64 & 6.87 & 0.34 & -3.17 & 0.51 & $(0.209)$ & 0.43 & $(0.9146)$ \\
\hline 23 & 6.64 & 5.69 & 1.11 & 3.07 & 8.68 & 0.32 & -2.98 & 3.56 & (1.05) & 0.79 & $(1.6688)^{* *}$ \\
\hline 24 & 6.00 & 4.00 & 1.42 & 6.15 & 8.45 & 0.69 & -4.45 & -0.15 & $(-0.049)$ & 0.73 & $(1.512)^{*}$ \\
\hline 25 & 7.73 & 5.49 & 1.35 & 9.41 & 9.55 & 0.95 & -4.06 & -1.68 & $(-0.431)$ & 0.40 & $(0.7979)$ \\
\hline 26 & 6.82 & 5.94 & 1.10 & 11.83 & 11.39 & 1.01 & -5.45 & -5.02 & $(-0.943)$ & 0.08 & $(0.1527)$ \\
\hline 27 & 5.73 & 6.14 & 0.88 & 14.17 & 11.35 & 1.22 & -5.22 & -8.44 & $(-1.65)^{*}$ & -0.34 & $(-0.6383)$ \\
\hline 30 & 5.98 & 8.01 & 0.71 & 14.61 & 10.96 & 1.31 & -2.95 & -8.63 & $(-2.229)^{* *}$ & -0.60 & $(-1.604)^{*}$ \\
\hline 31 & 4.47 & 12.77 & 0.33 & 9.13 & 16.24 & 0.54 & -3.48 & -4.66 & $(-0.812)$ & -0.22 & $(-0.5658)$ \\
\hline 32 & 2.47 & 10.24 & 0.21 & 6.41 & 16.89 & 0.36 & -6.65 & -3.94 & $(-0.705)$ & -0.15 & $(-0.3842)$ \\
\hline 33 & 5.28 & 14.06 & 0.35 & 4.75 & 18.01 & 0.25 & -3.95 & 0.53 & $(0.078)$ & 0.11 & $(0.2555)$ \\
\hline 34 & 4.63 & 11.45 & 0.38 & 5.77 & 16.77 & 0.33 & -5.32 & -1.14 & $(-0.19)$ & 0.05 & $(0.1242)$ \\
\hline 35 & 4.56 & 12.47 & 0.34 & 7.12 & 17.83 & 0.38 & -5.35 & -2.55 & $(-0.404)$ & -0.04 & $(-0.101)$ \\
\hline 36 & 5.03 & 15.96 & 0.30 & 2.18 & 14.39 & 0.13 & 1.57 & 2.86 & $(0.443)$ & 0.17 & $(0.3911)$ \\
\hline 37 & 2.00 & 13.24 & 0.13 & 3.44 & 12.36 & 0.25 & 0.88 & -1.44 & $(-0.265)$ & -0.13 & $(-0.294)$ \\
\hline 38 & 0.29 & 12.51 & 0.00 & 1.23 & 7.88 & 0.12 & 4.63 & -0.95 & $(-0.225)$ & -0.12 & $(-0.286)$ \\
\hline 39 & 0.60 & 11.59 & 0.02 & 1.54 & 7.64 & 0.16 & 3.94 & -0.94 & $(-0.228)$ & -0.13 & $(-0.321)$ \\
\hline Average $1-39$ & 3.329 & 8.61 & 0.40 & 4.78 & 11.6 & 0.37 & -2.89 & -1.37 & $(-1.897)^{* *}$ & 0.03 & $(0.359)$ \\
\hline
\end{tabular}


(b)

\begin{tabular}{|c|c|c|c|c|c|c|c|c|c|c|c|}
\hline \multicolumn{12}{|c|}{ Panel B: Big winner portfolios versus big losers portfolios } \\
\hline \multirow{2}{*}{$\begin{array}{l}\mathrm{T} \\
1\end{array}$} & \multirow{2}{*}{$\begin{array}{l}\text { BW } \\
(\%)\end{array}$} & \multirow{2}{*}{$\begin{array}{c}\text { BW S.D } \\
(\%) \\
5.31\end{array}$} & \multirow{2}{*}{$\begin{array}{c}\text { BW Sharpe } \\
\text { ratio }(\times 100) \\
0.64\end{array}$} & \multirow{2}{*}{$\begin{array}{c}\text { BL (\%) } \\
1.85\end{array}$} & \multirow{2}{*}{$\begin{array}{c}\begin{array}{c}\text { BL S.D } \\
(\%)\end{array} \\
4.54\end{array}$} & \multirow{2}{*}{$\begin{array}{c}\begin{array}{c}\text { BL Sharpe } \\
\text { ratio }(\times 100)\end{array} \\
0.34\end{array}$} & \multirow{2}{*}{$\begin{array}{c}\text { Difference in } \\
\text { SD (\%) } \\
0.78\end{array}$} & \multicolumn{2}{|c|}{$\mathrm{WML}_{\mathrm{B}} \quad(\%)$} & \multicolumn{2}{|c|}{$\begin{array}{l}\text { Difference in Sharpe ratio of } \\
\text { BW and BL }(\times 100)\end{array}$} \\
\hline & & & & & & & & 1.85 & $(0.918)$ & 0.30 & $(0.7294)$ \\
\hline 2 & 3.21 & 6.17 & 0.47 & 1.82 & 3.75 & 0.41 & 2.42 & 1.39 & $(0.671)$ & 0.06 & $(0.1598)$ \\
\hline 3 & 3.55 & 6.24 & 0.52 & 2.18 & 4.19 & 0.45 & 2.05 & 1.37 & $(0.632)$ & 0.07 & $(0.1756)$ \\
\hline 4 & 2.67 & 5.34 & 0.45 & 2.00 & 3.49 & 0.49 & 1.85 & 0.67 & $(0.358)$ & -0.04 & $(-0.1042)$ \\
\hline 5 & 3.29 & 5.83 & 0.51 & 2.68 & 2.72 & 0.88 & 3.11 & 0.61 & $(0.324)$ & -0.36 & $(-0.8851)$ \\
\hline 6 & 3.22 & 5.67 & 0.52 & 2.76 & 2.97 & 0.83 & 2.70 & 0.46 & $(0.249)$ & -0.31 & $(-0.7602)$ \\
\hline 7 & 2.19 & 5.74 & 0.33 & 2.25 & 3.32 & 0.59 & 2.42 & -0.06 & $(-0.031)$ & -0.26 & $(-0.63)$ \\
\hline 8 & 1.79 & 5.34 & 0.28 & 2.48 & 3.75 & 0.58 & 1.60 & -0.69 & $(-0.364)$ & -0.30 & $(-0.7353)$ \\
\hline 9 & 0.21 & 5.18 & -0.02 & 1.81 & 4.46 & 0.34 & 0.72 & -1.60 & $(-0.813)$ & -0.36 & $(-0.8747)$ \\
\hline 10 & -1.05 & 6.79 & -0.20 & 0.25 & 6.44 & -0.01 & 0.35 & -1.30 & $(-0.506)$ & -0.19 & $(-0.4936)$ \\
\hline 11 & -0.77 & 7.54 & -0.14 & 0.77 & 7.14 & 0.06 & 0.39 & -1.54 & $(-0.547)$ & -0.21 & $(-0.5431)$ \\
\hline 12 & -0.27 & 7.08 & -0.08 & 0.75 & 6.07 & 0.07 & 1.02 & -1.02 & $(-0.387)$ & -0.15 & $(-0.3878)$ \\
\hline 13 & -0.28 & 7.93 & -0.07 & 0.95 & 6.10 & 0.11 & 1.83 & -1.23 & $(-0.433)$ & -0.18 & $(-0.4501)$ \\
\hline 14 & 1.32 & 6.72 & 0.15 & 2.33 & 5.41 & 0.37 & 1.30 & -1.01 & $(-0.42)$ & -0.22 & $(-0.5658)$ \\
\hline 15 & 2.27 & 6.87 & 0.29 & 2.91 & 5.22 & 0.50 & 1.64 & -0.64 & $(-0.26)$ & -0.21 & $(-0.5291)$ \\
\hline 16 & 2.00 & 7.16 & 0.24 & 3.45 & 4.51 & 0.70 & 2.66 & -1.45 & $(-0.596)$ & -0.46 & $(-1.1306)$ \\
\hline 17 & 1.25 & 7.70 & 0.12 & 1.60 & 5.30 & 0.25 & 2.40 & -0.35 & $(-0.129)$ & -0.12 & $(-0.2999)$ \\
\hline 18 & 0.87 & 7.77 & 0.07 & 1.34 & 5.71 & 0.18 & 2.06 & -0.46 & $(-0.171)$ & -0.11 & $(-0.2712)$ \\
\hline 19 & 1.91 & 7.32 & 0.22 & 2.99 & 4.89 & 0.55 & 2.43 & -1.08 & $(-0.435)$ & -0.33 & $(-0.8234)$ \\
\hline 20 & 0.06 & 8.50 & -0.03 & 0.64 & 6.67 & 0.05 & 1.83 & -0.57 & $(-0.182)$ & -0.08 & $(-0.1901)$ \\
\hline 21 & 1.52 & 6.71 & 0.18 & 1.32 & 5.90 & 0.17 & 0.81 & 0.20 & $(0.078)$ & 0.01 & $(0.0219)$ \\
\hline 22 & 3.48 & 4.37 & 0.73 & 2.45 & 5.04 & 0.43 & -0.67 & 1.03 & $(0.543)$ & 0.30 & $(0.7481)$ \\
\hline 23 & 3.74 & 3.88 & 0.89 & 1.44 & 4.34 & 0.26 & -0.45 & 2.31 & $(1.388)^{*}$ & 0.62 & $(1.5472)^{*}$ \\
\hline 24 & 3.28 & 3.66 & 0.82 & 1.72 & 5.36 & 0.27 & -1.71 & 1.56 & $(0.827)$ & 0.55 & $(1.3518)^{*}$ \\
\hline 25 & 2.93 & 5.70 & 0.46 & 1.59 & 5.54 & 0.23 & 0.16 & 1.34 & $(0.583)$ & 0.23 & $(0.5585)$ \\
\hline 26 & 3.42 & 3.84 & 0.81 & 2.03 & 5.80 & 0.30 & -1.96 & 1.39 & $(0.676)$ & 0.52 & $(1.251)$ \\
\hline 27 & 2.63 & 5.91 & 0.39 & 1.30 & 4.80 & 0.21 & 1.12 & 1.34 & $(0.602)$ & 0.19 & $(0.4496)$ \\
\hline 28 & 2.12 & 5.36 & 0.34 & 1.17 & 5.84 & 0.15 & -0.47 & 0.95 & $(0.407)$ & 0.19 & $(0.4579)$ \\
\hline 29 & 3.52 & 3.03 & 1.07 & 0.49 & 4.08 & 0.05 & -1.05 & 3.03 & $(2.049)^{* *}$ & 1.02 & $(2.469)^{* * *}$ \\
\hline 30 & 3.87 & 2.21 & 1.62 & 2.29 & 3.17 & 0.63 & -0.96 & 1.58 & (1.488) & 0.99 & $(2.5452)^{* * *}$ \\
\hline 31 & 3.60 & 4.18 & 0.79 & 0.45 & 3.41 & 0.04 & 0.77 & 3.16 & $(2.106)^{* *}$ & 0.75 & $(1.9038)^{* *}$ \\
\hline 32 & 3.16 & 3.95 & 0.73 & 1.13 & 4.32 & 0.19 & -0.36 & 2.04 & $(1.262)$ & 0.53 & $(1.3655)^{*}$ \\
\hline 33 & 0.81 & 6.01 & 0.08 & 0.18 & 3.36 & -0.03 & 2.64 & 0.62 & $(0.32)$ & 0.12 & $(0.3003)$ \\
\hline 34 & 1.84 & 5.60 & 0.27 & -0.12 & 4.27 & -0.10 & 1.33 & 1.97 & $(0.995)$ & 0.37 & $(0.948)$ \\
\hline 35 & 2.33 & 6.80 & 0.30 & 0.17 & 3.29 & -0.04 & 3.51 & 2.15 & $(1.005)$ & 0.34 & $(0.853)$ \\
\hline 36 & 1.42 & 8.14 & 0.14 & 0.05 & 3.33 & -0.08 & 4.81 & 1.37 & $(0.545)$ & 0.21 & $(0.534)$ \\
\hline 37 & 1.19 & 8.76 & 0.10 & -0.48 & 3.02 & -0.26 & 5.74 & 1.67 & $(0.627)$ & 0.36 & $(0.912)$ \\
\hline 38 & -0.01 & 8.03 & -0.04 & -1.35 & 2.90 & -0.58 & 5.13 & 1.34 & $(0.549)$ & 0.53 & $(1.328)^{*}$ \\
\hline 39 & -0.44 & 8.29 & -0.09 & -1.14 & 3.21 & -0.45 & 5.08 & 0.70 & $(0.275)$ & 0.36 & $(0.9066)$ \\
\hline Average 1 - 39 & 1.89 & 6.09 & 0.35 & 1.33 & 4.56 & 0.23 & $1.5 \%$ & 0.59 & $(1.674)^{* *}$ & 0.12 & $(1.842)^{* *}$ \\
\hline
\end{tabular}


(c)

\begin{tabular}{|c|c|c|c|}
\hline \multicolumn{4}{|c|}{ Panel C: Winners versus losers } \\
\hline \multirow{2}{*}{$\begin{array}{l}\mathrm{T} \\
1\end{array}$} & \multirow{2}{*}{$\begin{array}{c}\mathrm{WML}_{\mathrm{s}-\mathrm{B}}(\%) \\
-0.21\end{array}$} & \multicolumn{2}{|c|}{ WML (\%) } \\
\hline & & 1.74 & $(0.729)$ \\
\hline 2 & -1.18 & 0.80 & $(0.347)$ \\
\hline 3 & -1.87 & 0.43 & $(0.16)$ \\
\hline 4 & 1.51 & 1.43 & $(0.486)$ \\
\hline 5 & -0.36 & 0.43 & $(0.172)$ \\
\hline 6 & -3.08 & -1.08 & $(-0.48)$ \\
\hline 7 & -5.48 & -2.80 & $(-1.141)$ \\
\hline 8 & -3.99 & -2.69 & $(-1.001)$ \\
\hline 9 & -1.32 & -2.26 & $(-0.814)$ \\
\hline 10 & -0.64 & -1.62 & $(-0.488)$ \\
\hline 11 & 1.12 & -0.98 & $(-0.357)$ \\
\hline 12 & 0.00 & -1.02 & $(-0.365)$ \\
\hline 13 & 0.99 & -0.73 & $(-0.279)$ \\
\hline 14 & -0.20 & -1.11 & $(-0.396)$ \\
\hline 15 & -0.36 & -0.82 & $(-0.283)$ \\
\hline 16 & 2.32 & -0.29 & $(-0.106)$ \\
\hline 17 & 2.05 & 0.67 & $(0.244)$ \\
\hline 18 & 2.21 & 0.64 & $(0.223)$ \\
\hline 19 & 3.19 & 0.51 & $(0.182)$ \\
\hline 20 & 3.07 & 0.96 & $(0.311)$ \\
\hline 21 & 2.48 & 1.44 & $(0.509)$ \\
\hline 22 & -0.52 & 0.77 & $(0.474)$ \\
\hline 23 & 1.26 & 2.93 & $(1.477)^{*}$ \\
\hline 24 & -1.71 & 0.70 & $(0.389)$ \\
\hline 25 & -3.02 & -0.17 & $(-0.08)$ \\
\hline 26 & -6.41 & -1.81 & $(-0.596)$ \\
\hline 27 & -9.78 & -3.55 & $(-1.2)$ \\
\hline 28 & -7.67 & -2.88 & $(-0.947)$ \\
\hline 29 & -11.50 & -2.72 & $(-1.001)$ \\
\hline 30 & -10.21 & -3.52 & $(-1.643)^{*}$ \\
\hline 31 & -7.82 & -0.75 & $(-0.222)$ \\
\hline 32 & -5.97 & -0.95 & $(-0.275)$ \\
\hline 33 & -0.10 & 0.57 & $(0.14)$ \\
\hline 34 & -3.11 & 0.41 & $(0.108)$ \\
\hline 35 & -4.71 & -0.20 & $(-0.05)$ \\
\hline 36 & 1.49 & 2.11 & $(0.508)$ \\
\hline 37 & -3.11 & 0.11 & $(0.029)$ \\
\hline 38 & -2.29 & 0.19 & $(0.061)$ \\
\hline 39 & -1.63 & -0.12 & $(-0.038)$ \\
\hline Average $1-39$ & -0.020 & -0.004 & $(-0.833)$ \\
\hline
\end{tabular}


monthly risk-adjusted return in 19 of the 39 months of portfolios formation, but it is statistically significant only for two of the 19 months. We conclude therefore that small-winner stock portfolios do not provide higher risk-adjusted returns than small-loser stock portfolios; the mean difference between the two beings 3 percent with a t-value of 0.359 .

The results in panel B report that there is a statistically positive difference in average monthly returns of large-winner stock portfolios and large-loser stock portfolios $\left(\mathrm{WML}_{\mathrm{B}}\right)$ during the period of 2010 to 2013. Large-winner stock portfolios generate higher average monthly returns than large-loser stock portfolios in 25 of the 39 months of portfolios formation, out of which only three months are statistically significant. The analysis indicates that large-winner stock portfolios outperformed large-loser stock portfolios. The average monthly of momentum profit in large size category is 0.59 percent with a t-value of 1.674. Furthermore, the results indicate that there is also statistically positive difference in average monthly risk-adjusted returns between large-winner stock portfolios and large-loser stock portfolios during the period of the study. Large-winner stock portfolios generate higher average monthly risk-adjusted return in comparison to large-loser stock portfolios in 22 of the 39 months of portfolios formation, but the difference is statistically significant in only 7 of the 22 months. This result leads us to conclude that the large-winner stock portfolios gain higher average monthly risk-adjusted returns than large-losers stock portfolios with a mean difference of 12 percent and t-value of 1.842 .

Panel C summarizes the overall momentum profit (WML) which is the equal weight of momentum profit in small size category and large size category. The results indicate that there is no momentum profit in Thailand during the period of 2010 to 2013. Although, a positive average monthly momentum profit is noted in 18 of the 39 months of portfolios formation, the results are statistically significant for only one of the 18 months. On the whole, the average monthly momentum profit over the period of the study is -0.4 percent with a t-value of -0.833 . This result is consistent with previous studies of momentum strategy in Thailand; Chui et al. [9] investigate the momentum return in eight Asian countries including Thailand and find that over the period of 1986 to 2000 momentum strategy is profitable and significant in Thailand for the period before crisis of 1997 and but is weak and not statistically significant in the post crisis years. They further state that after crisis only half of the countries in their sample generate positive momentum return and find no clear relationship between the performance of the strategy before and after the crisis.

\section{Conclusion}

Our results on momentum strategy confirm that there is statistically significant positive momentum profit in large size stocks category whereas there is negative momentum profit in small size stocks during the period of 2010 to 2013. Furthermore, the equal weighted average of momentum profit of both small and large size categories do not provide any indication of overall momentum profit.

\section{References}

[1] Jegadeesh, N. and Titman, S. (1993) Returns to Buying Winners and Selling Losers: Implications for Stock Market Efficiency. The Journal of Finance, 48, 65-91. http://dx.doi.org/10.1111/j.1540-6261.1993.tb04702.x

[2] Asness, C.S., Moskowitz, T.J. and Pedersen, L.H. (2013) Value and Momentum Everywhere. The Journal of Finance, 68, 929-985. http://dx.doi.org/10.1111/jofi.12021

[3] Fama, E.F. and French, K.R. (2012) Size, Value, and Momentum in International Stock Returns. Journal of Financial Economics, 105, 457-472. http://dx.doi.org/10.1016/j.jfineco.2012.05.011

[4] Griffin, J.M., Ji, X.Q. and Martin, J.S. (2003) Momentum Investing and Business Cycle Risk: Evidence from Pole to Pole. The Journal of Finance, 58, 2515-2547. http://dx.doi.org/10.1046/j.1540-6261.2003.00614.x

[5] Chui, A.C. and Wei, K. (1998) Book-to-Market, Firm Size, and the Turn-of-the-Year Effect: Evidence from PacificBasin Emerging Markets. Pacific-Basin Finance Journal, 6, 275-293. http://dx.doi.org/10.1016/S0927-538X(98)00013-4

[6] Daniel, K. and Titman, S. (2000) Market Efficiency in an Irrational World. National Bureau of Economic Research, Working Paper No. 7489.

[7] Hong, H., Lim, T. and Stein, J.C. (2000) Bad News Travels Slowly: Size, Analyst Coverage, and the Profitability of Momentum Strategies. The Journal of Finance, 55, 265-295. http://dx.doi.org/10.1111/0022-1082.00206

[8] Rouwenhorst, K.G. (1998) International Momentum Strategies. The Journal of Finance, 53, 267-284. 
http://dx.doi.org/10.1111/0022-1082.95722

[9] Chui, A. C., Wei, K.-C. and Titman, S. (2000) Momentum, Legal Systems and Ownership Structure: An Analysis of Asian Stock Markets. SSRN Scholarly Paper No. 265848.

[10] Chui, A.C.W., Titman, S. and Wei, K.C.J. (2010) Individualism and Momentum around the World. The Journal of Finance, 65, 361-392. http://dx.doi.org/10.1111/j.1540-6261.2009.01532.X

[11] Yen, J.Y., Sun, Q. and Yan, Y. (2004) Value versus Growth Stocks in Singapore. Journal of Multinational Financial Management, 14, 19-34. http://dx.doi.org/10.1016/S1042-444X(03)00036-7

[12] Basu, S. (1983) The Relationship between Earnings' Yield, Market Value and Return for NYSE Common Stocks: Further Evidence. Journal of Financial Economics, 12, 129-156. http://dx.doi.org/10.1016/0304-405X(83)90031-4

[13] Barber, B.M. and Lyon, J.D. (1997) Detecting Long-Run Abnormal Stock Returns: The Empirical Power and Specification of Test Statistics. Journal of Financial Economics, 43, 341-372. http://dx.doi.org/10.1016/S0304-405X(96)00890-2

[14] Fama, E.F. and French, K.R. (1998) Value versus Growth: The International Evidence. The Journal of Finance, 53, 1975-1999. http://dx.doi.org/10.1111/0022-1082.00080

[15] Ding, D.K., Chua, J.L. and Fetherston, T.A. (2005) The Performance of Value and Growth Portfolios in East Asia before the Asian Financial Crisis. Pacific-Basin Finance Journal, 13, 185-199. http://dx.doi.org/10.1016/j.pacfin.2004.07.001

[16] Hull, J.C. (2011) Fundamentals of Futures and Options Markets (Global Edition). Pearson Education Inc., Boston. 